\title{
Spectroscopic Characterization of Biofield Treated Metronidazole and Tinidazole
}

\author{
Mahendra Kumar Trivedi ${ }^{1}$, Shrikant Patil ${ }^{1}$, Harish Shettigar ${ }^{1}$, Khemraj Bairwa ${ }^{2}$ and Snehasis Jana ${ }^{2 *}$ \\ ${ }^{1}$ Trivedi Global Inc., 10624 S Eastern Avenue Suite A-969, Henderson, NV 89052, USA \\ ${ }^{2}$ Trivedi Science Research Laboratory Pvt. Ltd., Hall-A, Chinar Mega Mall, Chinar Fortune City, Hoshangabad Rd., Bhopal- 462026, Madhya Pradesh, India
}

\begin{abstract}
Metronidazole and tinidazole are widely used antimicrobial drugs against Gram-negative and Gram-positive anaerobic bacteria. The present study was aimed to evaluate the impact of biofield treatment on metronidazole and tinidazole using FT-IR and UV spectroscopy. The study was carried out in two groups i.e. control and treatment. Treatment groups were subjected to Mr. Trivedi's biofield treatment while no treatment was given to control group. FT-IR spectrum of treated metronidazole showed the impact of biofield treatment on frequency of characteristic functional groups such as $\mathrm{C}=\mathrm{C}$ (imidazole ring) stretching was appeared at lower frequency i.e. from $1600 \mathrm{~cm}^{-1}$ to $1553 \mathrm{~cm}^{-1}$. Likewise, $\mathrm{NO}_{2}$ asymmetric stretching and $\mathrm{C}-\mathrm{N}$ symmetric stretching were appeared at higher wave number i.e. $1479 \mathrm{~cm}^{-1}$ to $1501 \mathrm{~cm}^{-1}$ and $1070 \mathrm{~cm}^{-1}$ to $1077 \mathrm{~cm}^{-1}$, respectively. FT-IR spectrum of tinidazole showed shifting in absorption peak of C-N stretching to higher wavenumber from $1002 \mathrm{~cm}^{-1}$ (control) to $1022 \mathrm{~cm}^{-1}$. The wavenumber of aromatic $\mathrm{C}=\mathrm{C}$ bond (in imidazole) was shifted to lower frequency, which could be due to increases in conjugation effect. Further, increases in wavenumber of $\mathrm{NO}_{2}$ and $\mathrm{C}-\mathrm{N}$ in treated sample suggested the increased force constant and bond strength as compared to control. Because of higher conjugation effect and increased bond strength, the molecule supposed to be more stable. The UV spectra of both metronidazole and tinidazole showed the similar patterns of lambda max $\left(\lambda_{\text {max }}\right)$ with respect to their control. The FT-IR results of both drugs suggest that there was an impact of biofield treatment on atomic level of metronidazole and tinidazole, as compared to control.
\end{abstract}

Keywords: Metronidazole; Tinidazole; Biofield treatment; Fourier transform infrared spectroscopy; Ultraviolet spectroscopy

\section{Introduction}

Metronidazole and tinidazole are structurally similar synthetic imidazole derivative and widely used as antimicrobials against several infections such as infection of intra-abdominal, respiratory tract, skin, central nervous, oral and dental, bone and joint, etc. Both the metronidazole and tinidazole are prescribed widely in bacterial vaginosis caused by Gardnerella vaginalis. These drugs are also used before and after the gastrointestinal and gynaecological surgery to reduce the risk of postoperative anaerobic infection [1-4]. In vitro study of tinidazole showed comparable or in some cases greater antiprotozoal activity than, metronidazole [3]. Both metronidazole and tinidazole enter into bacterial cell, and convert into active nitroso free radical form either in cytoplasm of the bacteria or in specific organelles of protozoa. This free nitro-radical is may be responsible for the antiprotozoal activity of both drugs. The active form of both drugs is cytotoxic and binds nonspecifically to bacterial DNA. However, the actual mechanism of action has not yet been fully discovered but it includes the inhibition of DNA synthesis and DNA damage by oxidation, resulting in single-strand and double-strand DNA breaks that lead to DNA degradation and cell death. Aerobic microbes lack the electron-transport proteins with negative redox potential, hence, metronidazole is not active against aerobic microorganisms $[1,5,6]$. Anaerobic microbes have been acquired resistance to metronidazole by several ways like reduction efficiency of nitroreductase, active efflux, increased DNA damage repair, and presence of specific resistance genes (nim) [7-9]. Additionally, as per Crowell et al., increased resistances to metronidazole have also decreased sensitivity to tinidazole [10].

Both metronidazole and tinidazole possess some stability related difficulty. Metronidazole degrades in alkaline condition to ammonia and acetic acid [11]. Photo-stability of metronidazole showed a rearrangement and degradation products upon UV photolysis [12]. Tinidazole is also reported to decompose hydrolytically in alkaline conditions to its 2-methyl-4 (5)-nitroimidazole and 4-nitro isomer [13]. Therefore, an alternative approach, which can enhance the shelf life of less stable drug, could be advantageous to the pharmaceutical field.

Recently, biofield treatment is recognized as a new approach to alter several physical and structural properties at the atomic level of various living and non-living things $[14,15]$. As per Planck M, electrical current exists inside the human body in the form of vibratory energy particles like ions, protons, and electrons. These moving particles generates magnetic field in the human body [16,17]. Willem Einthoven discovered an electrocardiography in 1924 to measure the human biofield. Maxwell JC gave a hypothesis that all the electrical process happening in human body generates magnetic field [18]. It can be observe using some medical technologies such as electromyography, electrocardiography, and electroencephalogram. The electromagnetic field of the human body is known as biofield and energy associated with this field is known as biofield energy [19-21]. Mr. Trivedi has the ability to harness the energy from environment or universe and can transmit into any living or nonliving object(s) around the globe. The object(s) always receive the energy and responding into useful way. This process is known as biofield treatment.

Mr. Trivedi's biofield treatment has substantially changed the various physicochemical and structural properties of metals and ceramics $[15,22,23]$. Medicinal property and growth of ashwagandha were increased after exposure to biofield treatment [24]. Additionally, biofield treatment has significantly enhanced the yield, nutrient value, and quality of various herbs and agriculture products $[25,26]$. Moreover, the antimicrobial sensitivity, biochemical reactions pattern and biotype number of some pathogenic microorganism have also changed after biofield treatment [14,27].

Considering the impact of biofield treatment on living and nonliving things, the present study was aimed to evaluate the impact

*Corresponding author: Snehasis Jana, Trivedi Science Research Laboratory Pvt. Ltd., Hall-A, Chinar Mega Mall, Chinar Fortune City, Hoshangabad Rd., Bhopal462026, Madhya Pradesh, India, Tel: +91-755-6660006; E-mail: publication@ trivedisrl.com

Received June 28, 2015; Accepted July 24, 2015; Published July 27, 2015

Citation: Trivedi MK, Patil S, Shettigar H, Bairwa K, Jana S (2015) Spectroscopic Characterization of Biofield Treated Metronidazole and Tinidazole. Med chem 5 : 340-344 doi: 10.4172/2161-0444.1000283

Copyright: (c) 2015 Trivedi MK, et al. This is an open-access article distributed under the terms of the Creative Commons Attribution License, which permits unrestricted use, distribution, and reproduction in any medium, provided the original author and source are credited. 
of biofield treatment on metronidazole and tinidazole and its effects were analyzed at atomic level using FT-IR and UV-Vis spectroscopic techniques.

\section{Materials and Methods}

\section{Study design}

Metronidazole and tinidazole were procured from Sigma-Aldrich, MA, USA; and divided into two parts i.e. control and treatment. The control samples remained as untreated, and treatment samples were handed over in sealed pack to Mr. Trivedi for biofield treatment under laboratory condition. Mr. Trivedi provided this treatment through his energy transmission process to the treatment groups without touching the objects [14,27]. Subsequently, both the control and treated samples of metronidazole and tinidazole were analyzed using Fourier transform infrared (FT-IR) spectroscopy and Ultraviolet-Visible (UV-Vis) spectroscopy.

\section{FT-IR spectroscopic characterization}

FT-IR spectra were recorded on Shimadzu's Fourier transform infrared spectrometer (Japan) with frequency range of $4000-500 \mathrm{~cm}^{-1}$. The<smiles>Cc1ncc([N+](=O)[O-])n1CCO</smiles>

(a)

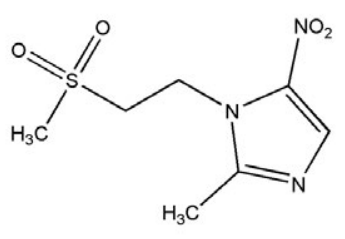

(b)
Figure 1: Chemical structure of (a) metronidazole and (b) tinidazole.
FT-IR spectroscopic analysis of metronidazole and tinidazole (Figure 1) was carried out to evaluate the impact of biofield treatment at atomic level like bond strength, and stability of structure.

\section{UV-Vis spectroscopic analysis}

UV-Vis spectra of metronidazole and tinidazole were acquired on a Shimadzu UV-2400 PC series spectrophotometer with $1 \mathrm{~cm}$ quartz cell and a slit width of $2.0 \mathrm{~nm}$. The analysis was performed using wavelength range of $200-400 \mathrm{~nm}$. This was performed to evaluate the effect of biofield treatment on structural property of tested drugs with respect to functional groups and their position.

\section{Results and Discussion}

\section{FT-IR spectroscopic analysis}

Functional groups present on the chemical structure of analyte sample give characteristic vibrational peak (stretching, bending etc.) on FT-IR spectra, which is unique for that particular functional group. These vibrational peaks interpreted for structural characterization of test compounds [28]. The FT-IR spectra of both control and treated metronidazole are shown in Figure 2. The control sample of metronidazole showed characteristic vibrational peak for $\mathrm{C}-\mathrm{H}$ stretching at $2991 \mathrm{~cm}^{-1}$. IR peaks at 1600 and $1523 \mathrm{~cm}^{-1}$ were assigned to $\mathrm{C}=\mathrm{C}$ and $\mathrm{C}=\mathrm{N}$ stretching, respectively. The $\mathrm{N}=\mathrm{O}$ asymmetric stretching was assigned to peak at $1479 \mathrm{~cm}^{-1}, \mathrm{CH}_{2}$ bending vibration peak was attributed to peak at $1466-1452 \mathrm{~cm}^{-1}$, and C-C stretching peak was assigned to peak at $1425-1426 \mathrm{~cm}^{-1}$. The absorption peaks at 1387 and $1356 \mathrm{~cm}^{-1}$ were assigned to $\mathrm{CH}_{3}$ bending and $\mathrm{N}=\mathrm{O}$ asymmetric stretching, respectively. Further, absorption peaks at 1275-1096, 1070 and $711 \mathrm{~cm}^{-1}$ were assigned to C-O stretching, C-N stretching, and $=\mathrm{C}-\mathrm{H}$ bending, respectively. FT-IR data of control metronidazole was well supported by the literature data [29].
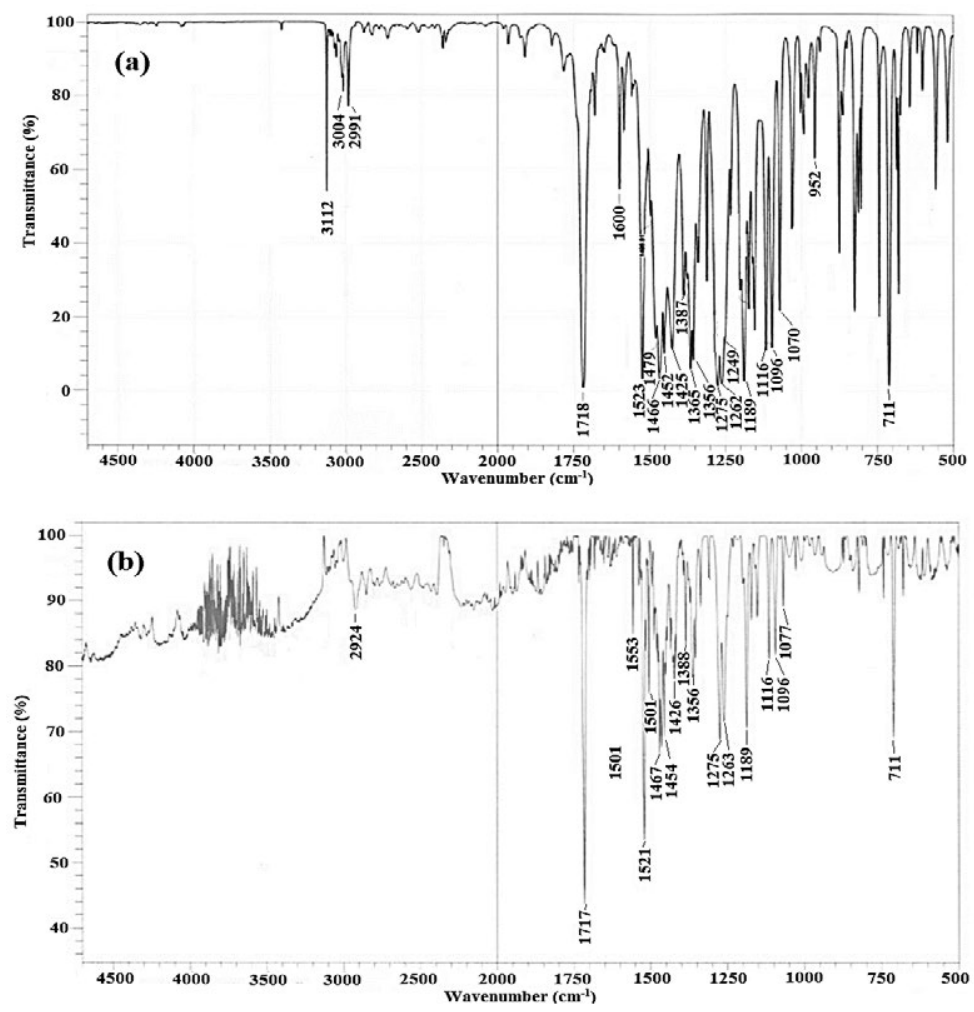

Figure 2: FT-IR spectra of metronidazole (a) control and (b) treated. 
The FT-IR spectrum of biofield treated metronidazole showed the vibrational peaks at 2924,1553 , and $1521 \mathrm{~cm}^{-1}$ that were attributed to $\mathrm{C}-\mathrm{H}$ stretching, $\mathrm{C}=\mathrm{C}$ (imidazole ring) stretching and $\mathrm{C}=\mathrm{N}$ (imidazole ring) stretching, respectively. Further, vibrational peaks at 1501, 14671454 , and $1426 \mathrm{~cm}^{-1}$ were assigned to $\mathrm{N}=\mathrm{O}$ stretching, $\mathrm{CH}_{2}$ bending, and $\mathrm{C}-\mathrm{C}$ stretching, respectively. The IR peaks at 1388 and $1356 \mathrm{~cm}^{-1}$ were assigned to $\mathrm{CH}_{3}$ bending and $\mathrm{N}=\mathrm{O}$ asymmetric stretching, respectively. Further, IR peaks at 1275-1096, 1077 and $711 \mathrm{~cm}^{-1}$ were assigned to C-O stretching, $\mathrm{C}-\mathrm{N}$ stretching, and $=\mathrm{C}-\mathrm{H}$ bending, respectively.

FT-IR spectra of control and treated tinidazole are shown in Figure 3. The FT-IR spectrum of control tinidazole exhibited a vibrational frequency at $2997-2901 \mathrm{~cm}^{-1}$ that was assigned to $\mathrm{C}-\mathrm{H}$ stretching. The IR peaks at 1601,1521 , and $1508 \mathrm{~cm}^{-1}$ were attributed to $\mathrm{C}=\mathrm{C}$ (imidazole ring), $\mathrm{C}=\mathrm{N}$ (imidazole ring), and $\mathrm{N}=\mathrm{O}\left(\mathrm{NO}_{2}\right)$ asymmetric stretchings, respectively. Absorption peaks at 1469 and $1430 \mathrm{~cm}^{-1}$ were attributed to $\mathrm{CH}_{2}$ bending and C-C stretching, respectively. The IR peaks appeared at 1365,1301 , and $1265 \mathrm{~cm}^{-1}$ were assigned to $\mathrm{N}=\mathrm{O}$ symmetric stretching,
$\mathrm{S}=\mathrm{O}$ asymmetric stretching and $\mathrm{C}-\mathrm{O}$ stretching, respectively. Lastly, the vibrational peaks at $1192-1123$ and $1002 \mathrm{~cm}^{-1}$ were assigned to $\mathrm{S}=\mathrm{O}$ symmetric stretching and C-N stretching, respectively. The FT-IR data of tinidazole were well supported by the literature data [30].

The FT-IR spectrum of biofield treated tinidazole showed the absorption peaks at $2998-2903,1558,1521$, and $1506 \mathrm{~cm}^{-1}$ that were attributed to $\mathrm{C}-\mathrm{H}$ stretching, $\mathrm{C}=\mathrm{C}$ (imidazole ring) stretching, $\mathrm{C}=\mathrm{N}$ (imidazole ring) stretching, and $\mathrm{N}=\mathrm{O}\left(\mathrm{NO}_{2}\right)$ asymmetric stretching, respectively. Further, vibrational peaks at 1467,1429 , and $1374 \mathrm{~cm}^{-1}$ were assigned to $\mathrm{CH}_{2}$ bending, $\mathrm{C}-\mathrm{C}$ stretching, and $\mathrm{CH}_{3}$ bending, respectively. The IR peaks at $1302,1265,1192$, and $1022 \mathrm{~cm}^{-1}$ were assigned to $\mathrm{S}=\mathrm{O}$ asymmetric stretching, $\mathrm{C}-\mathrm{O}$ stretching, $\mathrm{S}=\mathrm{O}$ symmetric stretching, and C-N stretching, respectively.

Altogether, the FT-IR data indicates a significant impact of biofield treatment at atomic level of both metronidazole and tinidazole as compared to control. The data showed a shifting of wavenumber of
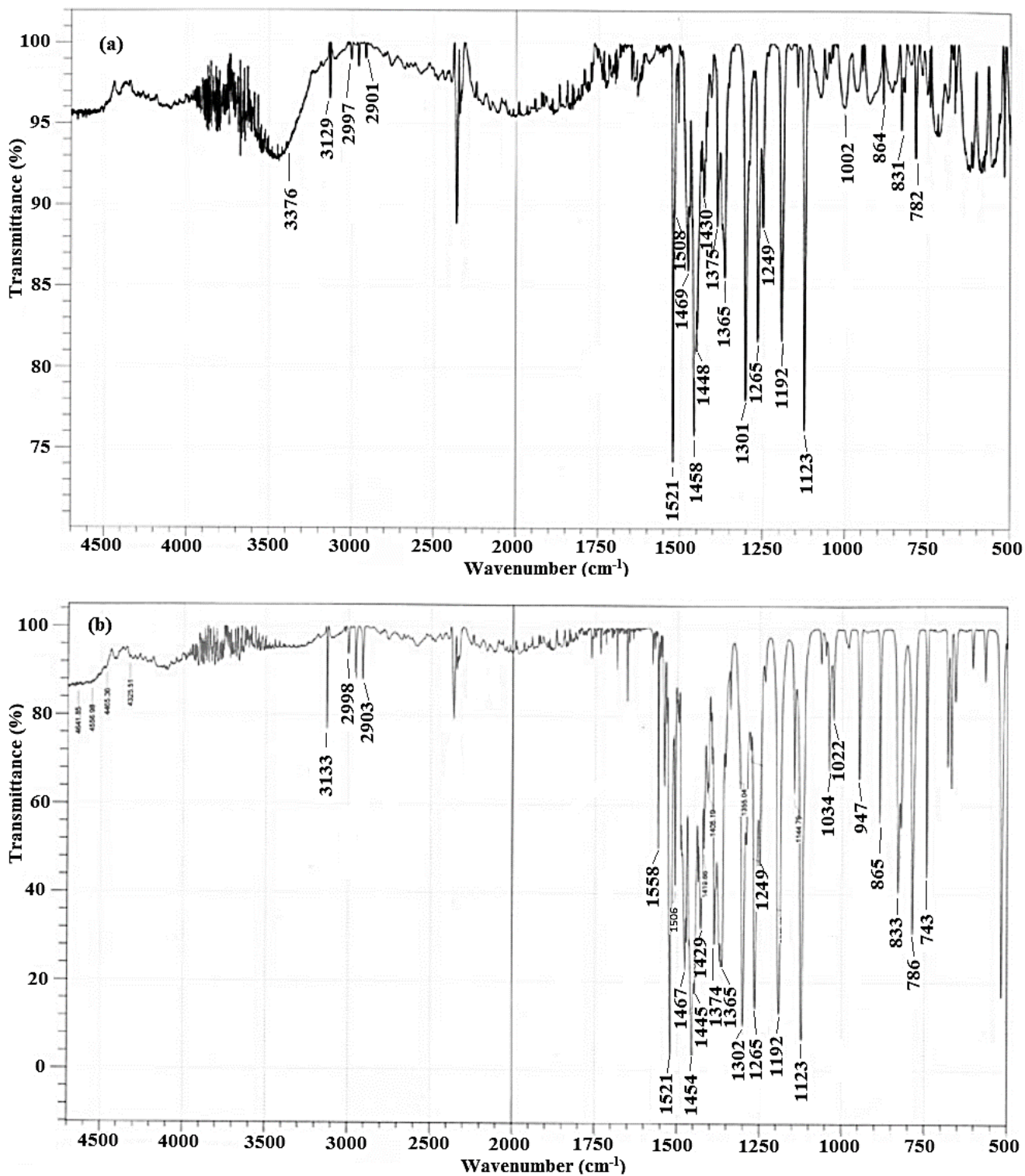

Figure 3: FT-IR spectra of tinidazole (a) control and (b) treated. 
$\mathrm{C}=\mathrm{C}$ (imidazole ring) bond towards lower frequency in treated sample of metronidazole (i.e. from $1600 \mathrm{~cm}^{-1}$ to $1553 \mathrm{~cm}^{-1}$ ) and tinidazole (i.e. from $1601 \mathrm{~cm}^{-1}$ to $1558 \mathrm{~cm}^{-1}$ ) indicates an enhanced conjugation effect in heterocyclic ring of both drug, as compared to control. It is well known that conjugation or resonance leads to increase in stability of chemical compounds [31,32]. Further, biofield treated metronidazole showed shifting of $\mathrm{N}=\mathrm{O}$ asymmetric stretching peak towards higher wavenumber from $1479 \mathrm{~cm}^{-1}$ to $1501 \mathrm{~cm}^{-1}$. This indicates an increase force constant of $\mathrm{N}=\mathrm{O}$ bond that might be due to increased bond strength after biofield treatment as compared to control. Similarly, the increased wavenumber of $\mathrm{C}-\mathrm{N}$ stretching in metronidazole (i.e. from $1070 \mathrm{~cm}^{-1}$ to $1077 \mathrm{~cm}^{-1}$ ) and tinidazole (i.e. from $1002 \mathrm{~cm}^{-1}$ to 1022 $\mathrm{cm}^{-1}$ ) also indicates the enhanced force constant and thus enhanced bond strength. Apart from these, $\mathrm{O}-\mathrm{H}$ stretching peak was observed in control sample of tinidazole that might be due to presence of moisture in sample.

Overall, the FT-IR result suggested that due to enhanced force constant and conjugation effect in some bonds, the chemical stability of respective bonds in biofield treated metronidazole and tinidazole could be enhanced as compared to control. As evidenced from literature report, both metronidazole and tinidazole possess some stability related hurdles like solution stability in alkaline conditions and photo-stability [11-13,33]. Therefore, enhancement in stability of some chemical bonds could also enhance the stability of these treated drugs, which could be beneficial for their shelf life.

\section{$\mathrm{UV}$-Vis spectroscopy}

UV spectra of control and treated samples of metronidazole are shown in Figure 4. The spectrum of treated sample showed similar pattern of lambda $\max \left(\lambda_{\max }\right)$ as compared to control, which indicates that chemical structure of control and treated metronidazole remained unchanged with respect to functional groups. UV spectra of control and treated sample of tinidazole are shown in Figure 5. It showed absorption peaks at 308 and $228 \mathrm{~nm}$ in control sample and 310 and 225 $\mathrm{nm}$ in treated sample, which indicates no significant change in lambda $\max \left(\lambda_{\max }\right)$ of treated sample as compared to control. Overall, the UV spectra of both the antimicrobials showed no significant changes in spectral pattern. Based on this, it could be concluded that chemical structure of both antimicrobials were not changed with respect to functional groups or their position, after biofield treatment. To the best of our knowledge, this is the first report showing an impact of biofield treatment on FT-IR and UV spectral properties of metronidazole and tinidazole.

\section{Conclusion}

Altogether, the results of present study showed the impact of biofield treatment on metronidazole and tinidazole. The FT-IR data of metronidazole showed an alteration in the wavenumber of some functional groups like $\mathrm{C}=\mathrm{C}, \mathrm{NO}_{2}, \mathrm{C}-\mathrm{N}$. Whereas, The FT-IR data of tinidazole showed an alteration in the wavenumber of some functional groups like $\mathrm{C}=\mathrm{C}$ and $\mathrm{C}-\mathrm{N}$, as compared to control. It might be due to some alteration at the atomic level through biofield treatment, which could lead to increase in stability of these bonds in the respective drugs as compared to control.

\section{Acknowledgement}

The authors would like to acknowledge the whole team of MGV Pharmacy College, Nashik for providing the instrumental facility.
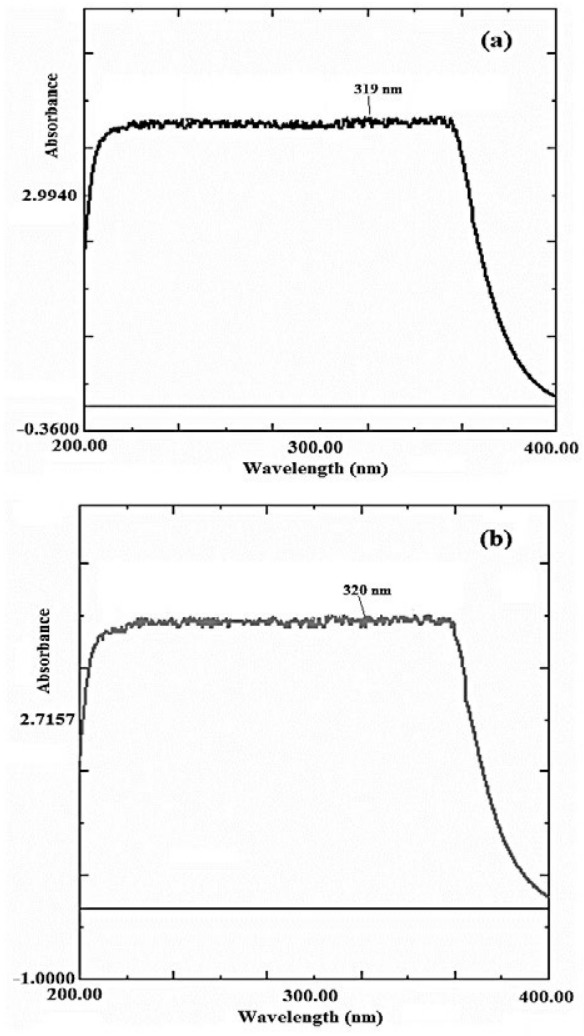

Figure 4: UV spectra of metronidazole (a) control and (b) treated.
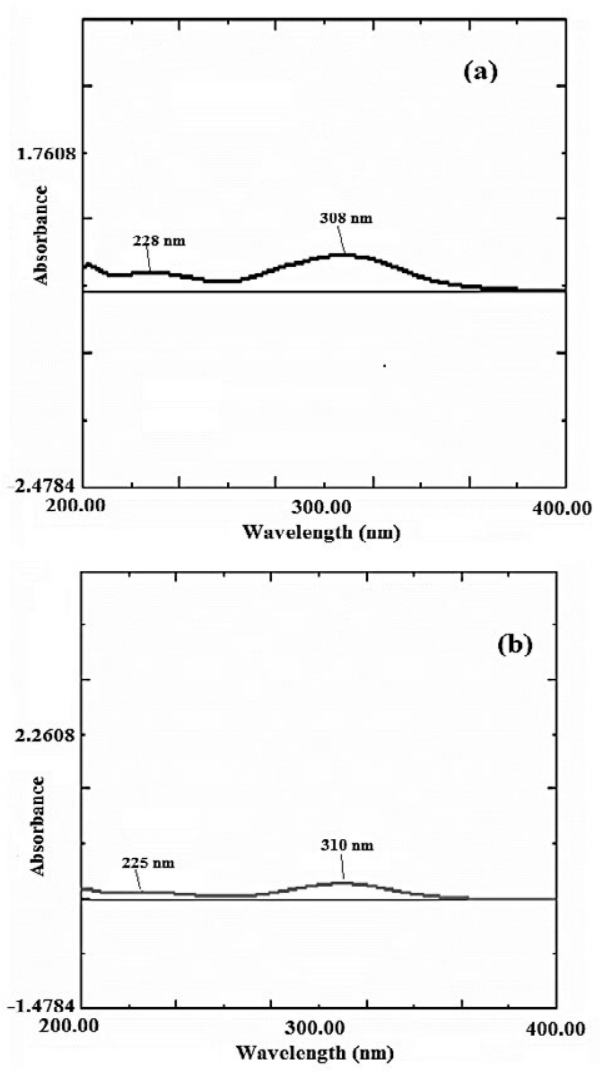

Figure 5: UV spectra of tinidazole (a) control and (b) treated. 
Citation: Trivedi MK, Patil S, Shettigar H, Bairwa K, Jana S (2015) Spectroscopic Characterization of Biofield Treated Metronidazole and Tinidazole. Med chem 5: 340-344. doi: 10.4172/2161-0444.1000283

\section{References}

1. Lofmark S, Edlund C, Nord CE (2010) Metronidazole is still the drug of choice for treatment of anaerobic infections. Clin Infect Dis 50 1: S16-23.

2. Atia AJ1 (2009) Synthesis and antibacterial activities of new metronidazole and imidazole derivatives. Molecules 14: 2431-2446.

3. Sawyer PR, Brogden RN, Pinder RM, Speight TM, Avery GS (1976) Tinidazole: a review of its antiprotozoal activity and therapeutic efficacy. Drugs 11: 423-440.

4. Packard RS (1982) Tinidazole: a review of clinical experience in anaerobic infections. J Antimicrob Chemother 10: 65-78.

5. Freeman CD, Klutman NE, Lamp KC (1997) Metronidazole: a therapeutic review and update. Drugs 54: 679-708.

6. Carmine AA, Brogden RN, Heel RC, Speight TM, Avery GS (1982) Tinidazole in anaerobic infections: a review of its antibacterial activity, pharmacological properties and therapeutic efficacy. Drugs 24: 85-117.

7. Land KM, Johnson PJ (1999) Molecular basis of metronidazole resistance in pathogenic bacteria and protozoa. Drug Resist Updat 2: 289-294.

8. Reysset G (1996) Genetics of 5-nitroimidazole resistance in Bacteroides species. Anaerobe 2: 59-69.

9. Theron MM, Janse Van Rensburg MN, Chalkley LJ (2004) Nitroimidazole resistance genes (nimB) in anaerobic Gram-positive cocci (previously Peptostreptococcus spp.). J Antimicrob Chemother 54: 240-242.

10. Crowell AL, Sanders-Lewis KA, Secor WE (2003) In vitro metronidazole and tinidazole activities against metronidazole-resistant strains of Trichomonas vaginalis. Antimicrob Agents Chemother 47: 1407-1409.

11. Baveja SK, Khosla HK (1975) Decomposition of metronidazole in aqueous solutions. Indian J Technol 13: 528.

12. Moore DE, Wilkins BJ (1990) Common products from gammaradiolysis and ultraviolet photolysis of metronidazole. Radiat Phys Chem 36: 547-550.

13. Salomies H1 (1991) Structure elucidation of the photolysis and hydrolysis products of tinidazole. Acta Pharm Nord 3: 211-214.

14. Trivedi MK, Patil S, Shettigar H, Bairwa K, Jana S (2015) Phenotypic and biotypic characterization of Klebsiella oxytoca: An impact of biofield treatment. J Microb Biochem Technol 7: 203-206.

15. Trivedi MK, Tallapragada RM (2008) A transcendental to changing metal powder characteristics. Met Powder Rep 63: 22-28, 31.

16. Planck M (1903) Treatise on Thermodynamics, (3rdedn), translated by Alexander OGG, Longmans, Green, London (UK).

17. Einstein A (1905) Does the inertia of a body depend upon its energy-content. Ann Phys 18: 639-641.
18. Maxwell JC (1865) A dynamical theory of the electromagnetic field. Philos Trans R Soc Lond 155: 459-512.

19. Rivera-Ruiz M, Cajavilca C, Varon J (2008) Einthoven's String Galvanometer: the first electrocardiograph. Tex Heart Inst J 35: 174-178.

20. Burr HS (1957) Bibliography of Harold Saxton Burr, Yale J Biol Med 30: 163-167.

21. Rubik B1 (2002) The biofield hypothesis: its biophysical basis and role in medicine. J Altern Complement Med 8: 703-717.

22. Trivedi MK, Patil S, Tallapragada PMR (2015) Effect of biofield treatment on the physical and thermal characteristics of aluminium powders. Ind Eng Manage 4: 151.

23. Trivedi MK, Nayak G, Patil S, Tallapragada RM, Latiyal O (2015) Studies of the atomic and crystalline Characteristics of ceramic oxide nano powders after biofield treatment. Ind Eng Manage 4: 1000161.

24. Altekar N, Nayak G (2015) Effect of biofield treatment on plant growth and adaptation. J Environ Health Sci 1: 1-9.

25. Patil SA, Nayak GB, Barve SS, Tembe RP, Khan RR (2012) Impact of biofield treatment on growth and anatomical characteristics of Pogostemon cablin (Benth.). Biotechnology 11: 154-162.

26. Lenssen AW (2013) Biofield and fungicide seed treatment influences on soybean productivity, seed quality and weed community. Agricultural Journal 8: 138-143.

27. Trivedi MK, Patil S, Shettigar H, Gangwar M, Jana S (2015) Antimicrobia sensitivity pattern of $P$ seudomonas fluorescens after biofield treatment. $J$ Infect Dis Ther 3: 222.

28. Jana S, Lakshman D, Sen KK, Basu SK (2010) Development and evaluation of epichlorohydrin cross-linked mucoadhesive patches of tamarind seed polysaccharide for buccal application. Int J Pharm Sci Drug Res 2: 193-198.

29. Pop C, Apostu S, Rotar AM, Semeniuc CA, Sindic M, et al. (2013) FTIR spectroscopic characterization of a new biofilm obtained from kefiran. J Agroalimentary Process Technol 19: 157-159.

30. Kumar GB, Annangi VK, Ahamed MG, Kumar GP (2013) Preparation and evaluation of Kollidon SR matrix tablets of tinidazole for colon specific drug delivery. Int J Sci Innov Today 2: 97-106

31. Seshadri TR, Subba Rao NV, Subrahmanyam B (1968) Effect of conjugation and complex formation on the Raman and IR frequencies of the carbony group. Proc Indian Acad Sci Sec A 68: 314-323.

32. Pavia DL, Lampman GM, Kriz GS (2001) Introduction to spectroscopy (3rdedn), Thomson learning, Singapore.

33. Verma P, Namboodiry V, Mishra S, Bhagwat A, Bhoir S (2013) A stability indicating HPLC method for the determination of metronidazole using ecofriendly solvent as mobile phase component. Int J Pharm Pharm Sci 5: 496-501. 